Teosofia: Indonesian Journal of Islamic Mysticism

Volume 6, Number 2, 2017: 87-108 DOI: 10.21580/tos.v6i2.3383

\title{
Sufistic Values in Suryomentaram Kawruh Jiwo
}

\author{
Nikmaturrahmah, ${ }^{1}$ Ahmad Musyafiq ${ }^{2}$ \\ ${ }^{1,2}$ Ushuluddin and Humanities Faculty of UIN Walisongo \\ nickrohmah@gmail.com
}

\begin{abstract}
The teaching of Sufism contains the noble values. The noble values can also be found in a variety of Javanis traditions and local wisdom, one of them is Kawruh Jiwa Ki Ageng Suryomentaram. The concept of Kawruh Jiwa is a method to achieve the soul condition without ego, it's also called "man without attribute", is relevant to the teachings of Sufism in the fight against the lust, and pursue the noble values of Sufistic wisdom. This study intends to reveal the Sufistic values in Kawruh Jiwa Ki Ageng Suryomentaram, by analyzing the relevance between the values in maqamat and ahwal with Kawruh Jiwa concept. The results showed that the concept of Kawruh Jiwa relevance to the values of maqamat and ahwal such as repentance (tawbah), asceticism (zuhd), patient (sabr), confidence (tawakkul), mujahadah, qanaah, tawadhu, and itsar. Thus, it can be said that the Kawruh Jiwa relevance with the Sufistic noble values, and reinforce those values in the frame of local wisdom.
\end{abstract}

Keywords: sufism; Kawruh Jiwa; maqamat and ahwal; a man with no attribute

\section{A. Introduction}

$\mathrm{H}$

uman life is sustained by values. ${ }^{1}$ Everyone moves based on a value he believes in and does something for the sake of upholding that value. The great civilizations in the world are built on the values agreed upon by a community that believes in them. The whole world is built in the dynamics of values that are mutually intertwined, dialogue, collaborate, and support each other. ${ }^{2}$ There are values that are universal that are agreed upon by all people in the world, and there are values

\footnotetext{
${ }^{1}$ Value always refers to something interesting, sought after, pleasant, in short something good. Value connotations are always positive. See K. Bertens, Ethics (Jakarta: Gramedia, 1993), 139.

${ }^{2}$ Values are natural things, however one tries to deny the existence of absolute values, it remains a fact that there are bad consequences when a person goes astray from values. See Donald Walters, Crises in Modern Thought, trans: Widhi Nugraha (Jakarta: Gramedia, 2003), 36.
} 
that are local, which are related to typical problems in each place in the world. ${ }^{3}$ Local values do not mean a value that is not agreed upon by all humans. Local values are derivative values, which their characteristic and practical are highly contextual with the dynamics of the problems that exist in each region. All local values that seem different, are only derivatives, and basically can be referred to values that are universal. The existence of differences in values, is actually just a matter of differences in understanding of a value that is very dependent on the capacity of individuals who interpret these values. ${ }^{4}$ Basically, every value is the same, universal, for all people around the world. Including the values of Sufism.

Sufism is an esoteric part of Islam, ${ }^{5}$ which is full of values. The tipping point of Sufism that attempts to connect every self to its true origin, namely God, and strives for a perfection of the soul that is not bound by matter, is the desire of every human being. ${ }^{6}$ In droves of people both in the East and in the West in studying Sufism, it is a phenomenon of longing for true nature. The values that exist in Sufism such as patience, asceticism, prioritizing others, love for others, are values that are universal and also widely found in local wisdom, especially in the archipelago. Islam entered the archipelago without causing major shocks and acceptable in Indoensian established cultural, social and political patterns. ${ }^{7}$ This is because the Islamic style that entered the archipelago uses the tenderness of Sufism. ${ }^{8}$ Islam with the tasawuf approach was the one who won the hearts of the people in the archipelago who had embraced Hinduism for centuries. ${ }^{9}$ Sufism with the values that are in it, much in accordance with the values adopted by the archipelago people since long ago. ${ }^{10}$ Archipelago people are already

\footnotetext{
${ }^{3}$ Each cultural locus develops its value system, and it is a form of wisdom in the context of the problems faced by each locality.

${ }^{4}$ Muhammad Zainur Rakhman, Mantyasih; Kitab Keabadian Cinta (Yogyakarta: Garudhawaca, 2016), 10 .

${ }^{5}$ Esoteric, the opponent is exoteric (Shari'a section). Sufism is an inner dimension of religion, which enters the tariqa, haqiqa, and makrifa regions. See Robert Frager, Sufi Psychology, translated: Hasmiyah Rauf (Jakarta: Zaman, 2014), 14.

${ }^{6}$ The analogy is the lamp with the source. Sufism tries to maintain the connection with the power source, not busy fixing the lamp. Without a power source, the light will not turn on. See Lynn Wilcox, Ilmu Jiwa Berjumpa Tasawuf, trans: Harimurti (Jakarta: Serambi, 2003), 11.

${ }^{7}$ Franz Magniz Suseno, Etika Jawa (Jakarta: Gramedia, 2003), 32.

${ }^{8}$ Sufism is seen as an Islamic teaching that is able to contribute to other religions and beliefs, including the people of the archipelago who have embraced Hinduism-Buddhism. See Samidi Khalim, Islam dan Spiritualitas Jawa (Semarang: RaSAIL Media, 2008), 33.

${ }^{9}$ Agus Wahyudi, Rahasia Kesempurnaan Makrifat Para Wali Jawa (Yogyakarta: Lingkaran, 2003), 78 .

${ }^{10}$ This suitability factor was successfully utilized by the Sufis in preaching Islam. Instead of changing local beliefs, the Sufis put more emphasis on the continuity between local teachings and Islam,
} 
accustomed to living a simple life, accustomed to living together with each other, caring for each other. The suitability of these values is what creates a beautiful blend of patterns. The touch of Islam (Sufism) with Javanese values for example, has succeeded in creating a unique and interesting Javanese style of Islam or Sufism. ${ }^{11}$ One of the touches is Ki Ageng Suryomentaram's thought called Kawruh Jiwa.

\section{B. Suryomentaram Living History and Kawruh Jiwo Discovery}

Kawruh Jiwa or in its first appearance is referred to as Kramadangsa Soul Science, originating from Suryomentaram's anxiety since he was young when he was looking for something called "uwong" (people). His search continued until he grew up.

Suryomentaram was born on May 20, 1892 at Ngayogyakarta Hadiningrat Palace, is the 55th son of 79 sons and daughters of Sri Sultan Hamengku Buwono VII, with the name Bendara Raden Mas Kudiarmaji. ${ }^{12}$ His mother was named B.R.A Retnomandoyo, as garwo (wife) ampeyan ${ }^{13}$ Sultan, who was the daughter of Patih Danurejo VI. ${ }^{14}$ B.R.M Kudiarmaji, together with his brothers, studied at Srimanganti School in the palace. He studied general science and religion, studied English, Dutch and Arabic. Islamic studies are obtained from palace clerics, one of whom is K.H. Ahmad Dahlan. ${ }^{15}$ Further education was a course at Klein Ambtenaar, after graduating, he worked for 2 years at the Dutch governor's office. ${ }^{16}$ Here, Suryomentaram sees the reality of the suffering of his people. As a prince, he felt sad and concerned about the condition of the people, one of which was forced planting. While he sits comfortably in the Palace, there are people out there suffering.

When he was 18 years old, he was appointed prince with the title Bendoro Pangeran Haryo Suryomentaram. ${ }^{17}$ However, even though he was the richest prince, ${ }^{18}$ he did not

so that no one felt replaced, let alone destroyed. See M. Solihin, Melacak Pemikiran Tasawuf di Nusantara (Jakarta: Raja Grafindo Persada, 2005), 25.

${ }^{11}$ The term Javanese Sufism is the result of da'wah that uses a compromise approach, as a tool which is quite effective in opening the hearts of the Javanese people. See Simuh, Sufisme Jawa, (Yogyakarta: Narasi, 2016), 24. 1986), 188

${ }^{12}$ Suryomentaram, Ajaran-Ajaran Ki Ageng Suryomentaram Jilid III (Jakarta: Inti Idayu Press,

${ }^{13}$ Second wife.

${ }^{14}$ Marcell Boneff, "Ki Ageng Suryomentaram, Pangeran dan Filsuf dari Jawa" (1892-1962), in Afthonul Afif, Matahari dari Mataram, Menyelami Spiritalitas Jawa Rasional Ki Ageng Suryomentaram (Depok: Penerbit Kepik, 2012), 4.

${ }^{15}$ Sri Teddy Rusdy, Epistemologi Ki Ageng Suryomentaram Tandhesan Kawruh Bab Kawruh (Jakarta: Yayasan Kertagama, 2014), 1.

${ }^{16}$ Suryomentaram, Ajaran-ajaran Ki Ageng III, 188.

${ }^{17}$ Suryoment aram, 188. 
feel happy. Life in the palace does not give him peace. He felt dissatisfied because he never met uwong. ${ }^{19}$ The Keraton's activities he experienced so far were the interactions of ndoro-abdi, which appeared from him were those who were worshiped, those who were hailed, those who were governed, so that what prevailed in them was to govern, to be angry, to plead. ${ }^{20}$ Suryomentaram considered all this time that he only met with fake people, including himself. His attitude as a person has been wrapped up in the clothes he wears made of silk. Also the various jewels she wears make it look like it is different to most people, she said: "Suryomentaram iki yen dijupuk semat, drajat, lan kramate, jing isih kari opo? Jing isih yo mung wong thok!"21 (This Suryomentaram, if he is taken his degree and position, the remaining is only uwong).

Suryomentaram assumed that if all the attributes of the world he had were released, then the only people left would be. There are no fake humans wrapped in silk clothes and power. So he tried to get rid of what he had; property, position and authority, with the aim of gaining joy, satisfaction, and meeting uwong. Of course, he could not just throw away all his possessions at once because it was against the situation and conditions, but his mind was increasingly dissatisfied and uneasy. To treat it, he often left the palace, went to places he considered able to bring calm. He explored Langse cave, Parangtritis Beach, and sacred tombs. Prawirowiworo, ${ }^{22}$ his best friend, also traveled and shared experiences when meeting. They went to religious leaders to learn the essence of religion and mystical experience. ${ }^{23}$ Although Prawirowiworo is a low person because he is only a court servant, Suryomentaram likes to be friend with him.

After a lot of wandering and learning, Suryomentaram increasingly believes that material ownership can inhibit happiness. He then gave all of his personal wealth free of charge, he gave his car to the driver and gave his horse to the horseman. ${ }^{24}$ At its peak,

${ }^{18}$ Suryomentaram beside being the son of the Sultan, he was also the grandson of the Patih Danurejo VI who was respected and rich, so that his wealth and power were even greater than other princes.

${ }^{19}$ Suryomentaram, 118.

${ }^{20}$ Ryan Sugiarto, Psikologi Raos Saintifikasi Kawruh Jiwa Ki Ageng Suryomentaram (Yogyakarta: Pustaka Ifada, 2015), 26.

${ }^{21}$ Suryomentaram, Ajaran-ajaran Ki Ageng Suryomentaram; Suryomentaram, if the property (semat), position (degree), and authority (kramat) are taken, all that remains is uwong (the person)!

${ }^{22}$ Prawirowiworo (d. 1960), was a close friend of Prince Suryomentaram, the oldest and closest friend he had. Both are cousins, but Prawirowiworo's status is much lower than Suryomentaram. Prawirowiworo is a court servant who was employed as a servant in the palace. See, Boneff in Matahari dari Mataram, Menyelami Spiritalitas Jawa Rasional Ki Ageng Suryomentaram (Depok: Ladybug Publisher, 2012), 5.

${ }^{23}$ Boneff, "Ki Ageng Suryomentaram", 5

${ }^{24}$ Boneff, 5-6. 
Suryomentaram left the palace, using the name Notodongso, disguised and went to Cilacap to sell batik. ${ }^{25}$

The heightened dissatisfaction was also driven by a series of life's problems and the refusal of his wishes by the Sultan. He was refused when he wanted to resign as prince, as he was also refused when he wanted to go to Mecca before. ${ }^{26}$ Then there was the incident of his grandfather's dismissal, Patih Danurejo VI, and his divorced mother. Especially before, his wife died right after giving birth to their son. ${ }^{27}$ The death of the closest and most loved ones made him be stricken, moreover he repeatedly begged and asked for his father's wisdom to cancel the dismissal and divorce, but was refused.

One day Suryomentaram went to Parangtritis which is located on the south coast of Jogja. Arriving at Opak River, blocked by floods. He was determined to throw himself until he finally gasped almost drowned and was helped by boatmen. ${ }^{28}$ This reckless event becomes an important experience that underlies Suryomentaram's findings about selfobservation, self-awareness, because he sees himself drowning.

In 1925, Suryomentaram remarried and took his family to Bringin, Salatiga. After marriage, Suryomentaram bears the name Ki Gede ${ }^{29}$ or Ki Ageng Suryomentaram, he is famous as a smart person and is visited by many people to be asked for advice, solutions, to drugs for inner healing or physical illness due to mental disturbances. One night in 1927, Nyi Ageng Suryomentaram was soundly asleep, awakened by Ki Ageng, and immediately said:

$\mathrm{Bu}$, wis ketemu jing tak goleki. Aku ora bisa mati. Jebul jing rumangsa durung nate ketemu wong, jing rumangsa cuwa lan ora marem ya kuwi wong, wujude si Suryomentaram. Diperintah cuwa, disrengeni cuwa, disembah cuwa, dijaluki berkah cuwa, dianggep dhukun cuwa, dianggep edan, cuwa, dadi pangeran cuwa, dadi wong dagang cuwa, dadi wong tani cuwa, ya kuwi wong jenenge Suryomentaram, banjur arep apa meneh? Saiki mung kari disawang, diweruhi, lan dijajaki. ${ }^{30}$

(Mom, I've found my look. I can not die. It turns out that he did not know anyone, who was disappointed and dissatisfied with him, was Suryomentaram. Rejected disappointed, scolded disappointed, dismayed, asked to be disappointed, considered a shy witch, considered disappointed, disappointed as a prince,

\footnotetext{
${ }^{25}$ Sugiarto, Psikologi Raos, 28.

${ }^{26}$ Boneff, "Ki Ageng Suryomentaram", 6.

${ }^{27}$ Sugiarto, Psikologi Raos, 28.

${ }^{28}$ Rusdy, Epistemologi Ki Ageng Suryomentaram, 11.

${ }^{29} \mathrm{Ki}$ is a term for people who are old and have superiorities or intelligence and are respected.

${ }^{30}$ See Suryomentaram in Ryan Sugiarto, Psikologi Raos, 32
} 
disappointed as a disgruntled farmer, a disgruntled farmer, a man named Suryomentaram, what would it be? Now just curated, discovered, and explored).

This experience was the starting point of Suryomentaram's discovery of Kawruh Jiwa and became the basis for him to formulate and compile the Kramadangsa Soul Science in supervising desires. Since then, Suryomentaram came to his friends to express their findings to meet uwong, meet himself. His friends who were told also felt like meeting people, meeting themselves. ${ }^{31}$ Every time he meets uwung (himself), Suryomentaram feels happy. This sense of pleasure is called a feeling of happiness, happiness that is free not dependent on place, time and circumstances. ${ }^{32}$

Suryomentaram died in 1962 due to illness, was buried in the family grave in the village of Kanggotan, Pleret, Bantul, Yogyakarta. ${ }^{33}$ Before Indonesia became independent, he participated in guerrilla warfare against the invaders and sparked the concept of war talismans, then another thought emerged about the souls of citizens, views about the world and others. His activities after the end of the independence war were holding lectures in various places. ${ }^{34}$

\section{Sufistic Messages in Langgar Book}

The Langgar book is a collection of Ki Ageng Suryomentaram's letters to his friends, containing pre-meditations on souls, meaning Ki Ageng's reflections before finding Kawruh Jiwa. The essence of the message in Langgar's book is about sih or love, as the primordial basis of humans in understanding reality, and associating with others. Sih or love, is the soul's most important need, as eating, drinking, and breathing is a physical need. Only by owning, man becomes complete and perfect. However, what is meant is not what is asked of others, but what comes from within yourself, because the process of introspection is intense and persevering. This is the real thing, which comes from within, not because of external gifts.

True sadness does not depend on giving love from others, but rather love that comes from yourself. True sih like a spring that radiates from within, flows and spills around. People who have true love, are referred to as those who are righteous (enough love), so that they do not require giving love from outside or from others.

How does this kind of love belong to person? This comes from a deep reflection on the nature of his amazing existence, and the existence of all things filled with beauty, so as to give birth to such a great and endless gratitude. A person with this kind of awareness, can be amazed and happy just by hearing the rhythm of his own heartbeat

\footnotetext{
${ }^{31}$ Sugiarto, Psikologi Raos, 32.

${ }^{32}$ Suryoment aram, Falsafah Hidup, 229.

${ }^{33}$ Suryomentaram, Ajaran-Ajaran Ki Ageng III, 196.

${ }^{34}$ Suryomentaram.
} 
and the sigh of his breath, especially by paying attention to the details of a colorful life; the sound of birds singing, gurgling of water, and friction of leaves, can vibrate the joy. Like wise when meeting fellow human beings, the feeling of joy is so deep, and gratitude swells. It is this kind of sadness that makes humans truly unclean, or possesses quality of security. True sadness is certainly far from the interests. True sih also eliminates the character of jealousy and arrogance, or the spirit of surpassing others (Raos ungkul). The teachings about this is according to mahabbah in Sufism. In Sufism, mahabbah or love are the most frequently discussed themes. It is said that God created because of love. Love is the reason for the existence of everything. The teaching about this matter is very much in tune with Sufism, and prevents a person from having a heart disease such as envy and arrogance because he does not understand the meaning of true love needs. This teaching is the starting point for entering Kawruh Jiwa with a more established concept.

\section{Sufistic Message in the Book of Teachings of Ki Ageng Suryomentaram}

The book of teachings of $\mathrm{Ki}$ Ageng Suryomentaram is a collection of lecture transcripts that contain a complete and relatively systematic from the teachings of $\mathrm{Ki}$ Ageng Suryomentaram whose core is Kawruh Jiwa. The book Teachings of Ki Ageng Suryomentaram begins with the concept of happy science. This discussion of happy science is the beginning of Suryomentaram's discourse on human taste (raos), which is closely related to karep (desire). It is this human desire that is the source of suffering, and the further away from true happiness. True happiness can only be obtained when a person succeeds in understanding his own desires (nyawang karep), freeing himself and being a supervisor of desires. This is then explained in a detail and clear manner, from how the desire to form the identity and attributes of a person called kramadangsa, even explained eleven notes which are human desires that compose his personal life from birth to adulthood, as well as the process of human release from attributes arranging his life, namely the birth of a human without characteristics. All the details of the teaching are basically a thought about lust and a method to break away from that lust, in a rational and practical way.

Someone who understands the concept of Kawruh Jiwa, can understand his own desires, become a supervisor, and is able to release his attributes, so in principle he has succeeded in conquering lust. The process of controlling and subduing lust is the essence of Sufism, where every Sufi needs to perform mujahadah and riyadhah in order to overcome it. It can be said, Kawruh Jiwa is a method of rational mujahadah in breaking away from the trap of lust.

This is the core theme in the book of Teachings of Ki Ageng Suryomentaram, which is then discussed by other sciences as the development of the core theme. Sciences such as Kasunyatan, marriage, livelihood, etc., are basically practical developments in a casuistic manner from the Kawruh Jiwa concept.

\section{E. Kawruh Jiwa Concept, Dialogue Between Psychology and Sufism}


The Kawruh Jiwa concept relies on dimensions that exist in humans that show the level of his soul. Every human being experiences various events since birth. It is this variety of life events that humans experience that keeps humans on record. The term notes in Kawruh Jiwa means that, every human being recorded in his consciousness, whatever is experienced throughout his life. ${ }^{35}$ These records form the identity of "me" or the self which in Suryomentaram's term is called Kramadangsa. Kramadangsa is what turns when someone is called his name. ${ }^{36}$ A self identity from the results of a record during his life, which forms a totality of "me". That note is just an attribute. An actual addition is not me who is true.

The dimension stage from the beginning of the human record until "rue me" happens when someone's process records, he is referred to as the record keeper. ${ }^{37}$ This note taker is the first basic human dimension. Furthermore, the records of each human being are of course different from one another. However, there are general similarities in the notes that can be grouped or classified. In Kawruh Jiwa, there are eleven groups of records that are generally owned by every human being. With eleven notes in detail, everyone's soul can be well recognized. The description of eleven notes is as follows. ${ }^{38}$

First, property records. Its contents are housing, land, livestock, gold jewelry, and so on. The nature of this property record remains, if reduced, taken, angry but if assisted, added, then laughs happily. Second, honor record. Its contents are tradition and daily procedures that show honor. How to shake hands, how to nod, and how to bend. Third, the record of power. It contains all kinds of ownership in his power. Fourth, family records. This note contains children, wife, husband, niece, and other relatives. Fifth, class notes. This note contains the stat us of a person, for example a priyayi, or a worker, or a farmer. Sixth, nationality record. Nationality records are naturally realized notes, as a consequence of life. For the example the Indonesian nation, the American nation. Seventh, type note. The type in question is human type. This type distinguishes humans from other creatures, such as animals, plants, and so on. Eighth, intelligence note. Contains all kinds of skills such as dancing, martial arts, cooking, and others. Ninth, kebatinan (esoteric dimension) record. Contains a conception of trust in certain teachings. Tenth, scientific record. Contains knowledge about the techniques and manufacturing of various needs. Eleventh, record of life. Contains notes of various memories and experiences generated by life. 1986), 31 .

${ }^{35}$ Suryomentaram, Ajaran-Ajaran Ki Ageng Suryomentaram Jilid II (Jakarta: Inti Idayu Press,

${ }^{36}$ Suryomentaram, 52.

${ }^{37}$ Suryomentaram, 53.

${ }^{38}$ Suryoment aram, 57-59. 
Chart of Kramadangsa: ${ }^{39}$

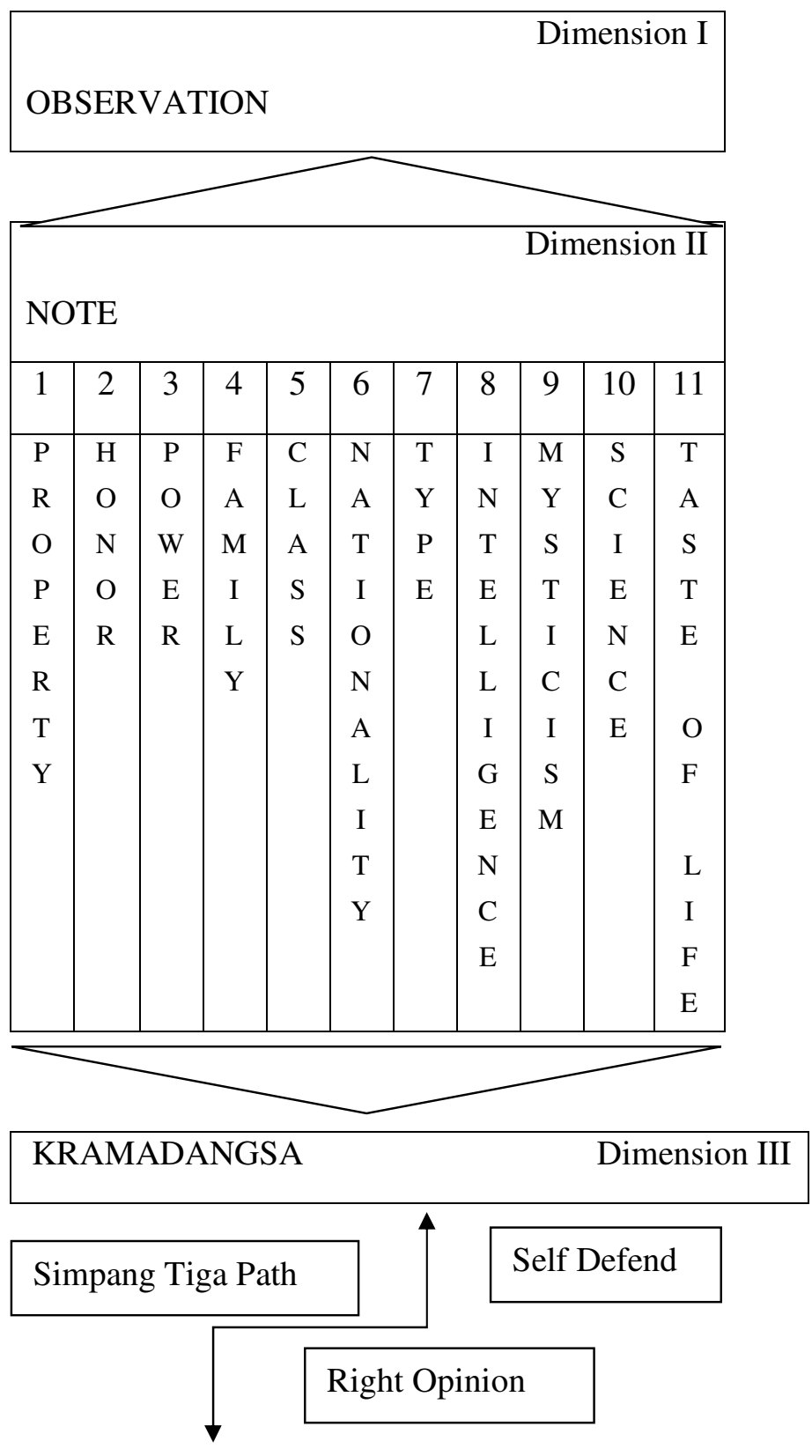

${ }^{39}$ Suryomentaram, 57. 


\section{HUMAN WITHOUT CHARACTER Dimension IV}

When this record is grouped in eleven notes, humans are in the second dimension. Then, the eleven notes formed the identity of "me" called kramadangsa, which is the totality of eleven notes. These 11 notes, each of which demands attention and is fulfilled by the kramadangsa. It can be said that me-kramadangsa are slaves who serve eleven employers. When Kramadangsa strives to fulfill the orders of the eleven employers, that's when someone is in the third dimension, which contains a struggle to be relentlessly happy. ${ }^{40}$

When humans are in this third dimension, humans will experience an intersection, whether he will defend his cremation, or can release the cramps into what is called a human without characteristics, namely humans without self, without attributes, who succeed in freeing themselves from the bondage "me" attribute, towards true me. Humans at this stage are in the fourth dimension. ${ }^{41}$

Humans in general, dwell on the third dimension, which makes it turn around in its own self. Humans do a lot of defense against their cramps when they feel urged. ${ }^{42}$ Man defends desperately when his identity is attacked, even though it's not his true self. Humans are busy defending their attribute identity, so that their lives have never experienced peace. Humans are always vulnerable to conflict, even with themselves. Failure to recognize the real me, while busy defending me attribute, this is what makes the problem that never ends. The problems experienced by every human being in the third dimension are basically the same, the defense of the true identity is only an attribute, repeated in every event in his life. This makes anxiety in the human psyche, which ultimately causes a mental shock, or a sick soul.

Humans who make it past the intersection, meaning that they succeed in releasing their cramps, being human without traits, will experience true happiness. ${ }^{43}$ Humans in this fourth dimension can never be hurt, never feel suffering, nor do they have a sense of pride or jealousy. Humans without traits are complete human prototypes, which have all the noble values that basically correspond to Sufistic values.

In the discussion of Psychology, Darmanto Jatman mentions that the concept of the intersection between records and their nature, me-kramadangsa with true me has a resemblance to the concept of id-ego and superego in psychoanalysis. Id is the basic

\footnotetext{
${ }^{40}$ Suryomentaram, 63.

${ }^{41}$ Suryomentaram, 64.

${ }^{42}$ Suryomentaram, 65.

${ }^{43}$ Suryomentaram, 66.
} 
instinct of the subconscious within a person, the ego is a slave to an id which is always required to carry out the wishes of the id, the norm that a person has is always in dialogue with the ego (me-kramadangsa). Although similar, according to the author both have fundamental differences. Id is dominated by sexual drive and aggression, while the human record is dominated by something else, namely the sacred degrees. In the Javanese philosophy of life, it seems that honor and self-esteem are more important than mere fulfillment of sexual desire. The possibility of the degrees and sacredness coming from the impulse of aggression is true, the urge to defeat, surpass, but not in order to harm and destroy the opponent as the animal wants to rule by killing all of its opponents. The background of Freud and Suryomentaram's life has similarity, that they are both living in times of war. But the family background is different. Neither is the habit between the two, Freud is called to experience a less pleasant phase of life due to his bad lifestyle. While Suryomentaram lives a simple, healthy life.

If you look further, chaotic souls not only treat human beings as objects that can be driven and controlled, but the spirit of the soul considers humans as creatures who have intentions who are able to think, feel and make their own decisions. Therefore, Suryomentaram in responding to him, made an effort to fight the taxon in order to fade with himself and his students. Suryomentaram views uwong positively and respects their humanity. Everyone can treat themselves, consulting with other people is one way to get the truth to themselves, but self-potential remains the basis and reference.

In the world of Sufism, humans are called to have angelic potential and potential for evil. Humans can reach noble degrees equal and surpass angels, or can reach a degree lower than darkness. All depends on the man himself, man is endowed with reason to think, heart to feel, then the decision is up to humans, where he wants to face and take sides.

Manungsa tanpa tenger (man without atributes), occupies a position similar to nafsmutmainnah, a calm soul. As for the differences in terms and languages, it cannot be a measure that they are different meaningfully and essentially. Kawruh Jiwa is typical of Java and is not thick with Arabic or Persian terms. Nafs-muthmainnah is a calm, nonturbulent and stretching mental condition caused by the balance of heart and mind in living life. In Sufism literature, Robert Frager gathers soul levels based on the opinions of the Sufis, namely the mineral spirit (spine), vegetable (liver), animal (heart), personal (brain), human (spiritual heart), sirr (spiritual heart / fuad / more-inner-heart) and sir alasrar (spiritual heart / lubb / deepest heart). ${ }^{44}$ Kawruh soul can deliver someone to the degree of fuad, if the training he does is very strict and earnest. As for the achievement of the lubb position, it requires synergy with a sense of divinity with the practice of Sufism.

\footnotetext{
${ }^{44}$ Robert Frager, Psikologi Sufi, 167.
} 
Kawruh Jiwa gives the opinion that human beings always keep a record, in line with Suhrawardi al-Maqtul's opinion, ${ }^{45}$ that humans have an external sense of sensation, namely the sense of sight, listener, kisser, taste and touch. This external absorption is found in humans and animals. Then the absorption power in (the inner senses), which includes the power of imagination, the power of thinking, the power of estimation, and the power of the guard. Imagination is a place of storing impressions that come from outside. Thinking power, functions as a compiler, selector, conclusion maker of incoming impressions. Power estimation functions as a harmonizer of reason work and tends to counteract the work of reason. Power guard, serves as a reminder of all events.

Derived from these powers, humans record and store it in record form that will shape a person's character and personality and become a person's capital in obtaining happiness. Happiness in Sufism has a level, according to the Maqamat which is successfully pursued and ahwal experienced and given to the Sufis. In the midst of a soul, humans can feel the perfect happiness depends on the effort and understanding taken by someone in seeing Kasunyatan (reality) and succeed in exploring the realm of thought and nature. Reflection of the divine energy can be obtained by someone by digging a well as deep as possible to exit the spring, or flowing the well with water imported from outside. In gaining knowledge and truth about the nature of soul and happiness, the Sufis put forward intuition in their minds, Suryomentaram put forward the sense and the taste. Both can bring people to happiness and come to Allah.

\section{F. Sufistic Values in Kawruh Jiwo}

Sufistic values are values contained in Sufism. ${ }^{46}$ These values are the essence of every Sufism practice which is the noble values that characterize a Sufi. Sufistic values are very diverse and style, but in general, the values uprooted are summarized in the concepts of Sufism called maqamat and ahwal. Maqamat is the plural form of the word

Table of Dynamics of Happiness in Kawruh Jiwa ${ }^{47}$

\begin{tabular}{|c|c|c|c|}
\hline $\begin{array}{c}\text { DESIRE } \\
\text { (expand-shrink) }\end{array}$ & INTROSPECTIVE & RESULTS & \\
\hline Happy-Hard & \multirow{3}{*}{$\begin{array}{l}\text { Sight } \\
\quad \downarrow \\
\text { Seeds Sight } \\
\quad \downarrow\end{array}$} & Fortune & \\
\hline Envy- Distribution & & Feeling Equal & Peace \\
\hline Regret- Worried & & Feeling Eternal & Resilient \\
\hline
\end{tabular}

${ }^{45}$ Amroeni Drajat, Suhrawardi (Yogyakarta: LKiS, 2005), 251.

${ }^{46}$ Sufism is essentially derived from the word shafa, which is holiness. Sufism teachings are full of noble universal values. See al-Hujwiri, Kasyful Mahjub, trans.: Suwardjo Muthary, (Bandung: Mizan, 1997), 40 .

${ }^{47}$ Ryan Sugiarto, Psikologi Raos, 66. 


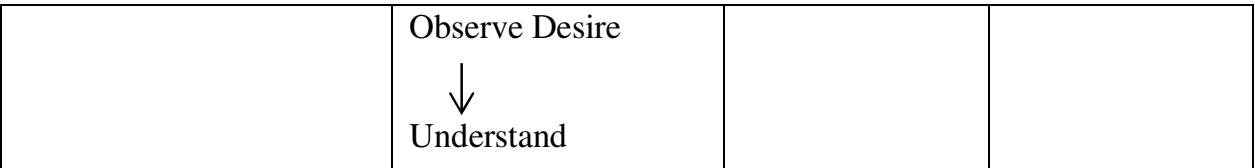

maqam, which in language means rank or degree. In English, maqamat is called as stations or stages. ${ }^{48}$ In terms of Sufism, maqamat is a spiritual station that shows the position of a servant before God, as a result of worship and struggle against lust. ${ }^{49}$ While ahwal is the results or spiritual conditions that arise from the maqamat. ${ }^{50}$ Ahwal is a spiritual status and a condition that is not permanent, which penetrates into the heart of a Sufi. ${ }^{51}$ The elements of the maqamat and awal, which contain Sufistic values include: Zuhud, Sabar, Mujahadah, Tawakkal, Qana'ah, Tawadhu' (humble), and Iśar (prioritizing others).

The concept of human without character in Kawruh Jiwa of Ki Ageng Suryomentaram is a local wisdom that describes the stages of the human dimension. The method of removing cramps into humans without traits is basically a strategy of control over desire. If Kramadangsa is likened to a slave who serves eleven employers (eleven attribute records), then recognizing the demands of eleven employers' wishes, then watching them is a way for cremation to escape slavery and become human without character.

The point of stress of the chaotic soul in the supervision of desire is part of the teachings of Sufism which also aims to subdue lust, namely desires. Kawruh Jiwo teaches how a person recognizes his own desires, and makes distance, that desire is not his true self. Desire which, in terms of kawruh, a spirit of ever-expanding (expanding and shrinking) is the upstream of various human suffering and distress.

Desire is the upstream of the emergence of problems and problems of unhappiness. Many people misperceive their desires. Ki Ageng stated: "The opinion that the achievement of desire causes a sense of happiness or does not achieve the desire to cause harm, is clearly wrong." 52

The achievement of desire does not guarantee the appearance of happiness. ${ }^{53}$ This is because the desire is elastic, or expands. After one wish is fulfilled, it will appear a

\footnotetext{
${ }^{48}$ Miswar, "Maqamat: Tahapan yang Harus Ditempuh dalam Proses Bertasawuf", Jurnal IANSIRUPA, Vol. 1, No. 2, 2017.

${ }^{49} \mathrm{Abu}$ Nashr as-Sarraj, al-Luma': Rujukan Lengkap Ilmu Tasawuf, trans: Wasmukan, (Surabaya: Risalah Gusti, 2014), 87.

${ }^{50}$ As-Sarraj, al-Luma': Rujukan Lengkap, 88.

${ }^{51}$ Laleh Bakhtiar, Mengenal Ajaran Kaum Sufi, trans: Purwanto, (Ujungberung: Marja, 2008), 114.

${ }^{52}$ Suryomentaram, Ajaran-ajaran Ki Ageng Suryomentaram Jilid I, 1.

${ }^{53} \mathrm{Ki}$ Ageng Mantyasih, Kawruh Begja Sawetah; Jabaran Ilmu Keberuntungan Ki Ageng Suryomentaram, (Semarang: Dahara Prize, 2013), 7.
}

Teosofia: Indonesian Journal of Islamic Mysticism, Volume 6, Number 2, 2017 
derivative or development of another desire. ${ }^{54}$ So, there was no time for someone to feel happiness, hurriedly covered by his mind in reaching the next wish. This happens continuously, endlessly, until humans reach thousands of desires, the happiness obtained is only temporary.

Submission of desires is at the core of the teachings of the Sufis. Thus the teachings of Kawruh Jiwa Ki Ageng Suryomentaram, are also teachings that are full of sufistic values. In detail Sufistic values in Kawruh Jiwa include:

\section{The Value of Taubah in Kawruh Jiwa}

A person who has achieved his / her level of nyawang karep (supervising desire) means that he/she has seen and understands the nature of his / her wishes, which if obeyed will stretch and if left unchecked. He is aware and understands that it is beautiful and difficult, temporary. Likewise, the nature of meri-pambagen and getun sumelang, envy and feeling like they want to win by themselves if they are obeyed will increase. Awareness of mortality in these traits is a person's starting point in opening his soul's cleansing gates. Understanding to stop obeying the desires of me-kramadangsa and preparing to explore the true me so that the soul will be filled with good thoughts and feelings and deliver it to happiness.

\section{The value of Zuhud in Kawruh Jiwa}

Zuhud is free from the attachment of things that are worldly and material. ${ }^{55}$ Zuhud is also interpreted as a mental attitude away from the world for the sake of akherat. ${ }^{56}$ However, the meaning of zuhud does not mean escaping from the world, but facing the world with a manly attitude, that the world is only a means not a goal. Zuhud is looking for a balance of soul between spiritual values and material needs. ${ }^{57}$ The point is that there is no heart dependence. As expressed by Ki Ageng Suryomentaram that someone who is successful in watching over his desires is someone who is free from attachment to the attributes of the world. In terms of Kawruh Jiwa, human beings who are zuhud are human beings who are free from cramps, or become human beings without characteristics. The essence of chasing the world is a demand that demands to be obeyed. Whereas the desire is always straightforward. If it is followed, it will increase, if it is restrained it will collapse (shrink). Suryomentaram tells us that the initial assumption, we assume that if desire is achieved then we will be happy. Whereas if it is not achieved it will be harmed. In fact, after thousands of desires have been achieved, humans are still not happy, but happy for a while, then hard again. So if the desire is not

\footnotetext{
${ }^{54}$ Suryomentaram, Ajaran-ajaran Ki Ageng I, 1

${ }^{55}$ al-Qusyairi, Risalah Qusyairiyah, trans: Umar Faruq (Jakarta: Pustaka Amani, 2013), 155.

${ }^{56}$ Amin Syukur, Sufi Healing (Jakarta: Erlangga, 2012), 59.

${ }^{57}$ Amin Syukur, Zuhud di Abad Modern (Yogyakarta: Pustaka Pelajar, 1997), 179.
} 
fulfilled, it will be shrink. The more it is not fulfilled, it will be impossible and suffice to be sufficient. Shrink will stop when the desire is reached, and after reaching it must be stretched again. If it is not reached, it will be possible again. It will be in the the expandshrink process. ${ }^{58}$

From this basis of thinking, the practice of zuhud which was carried out and offered by Ki Ageng Suryomentaram, did not necessarily leave things that were worldly, as he said in the book Langgar, that humans should not forget their live. ${ }^{59}$ Because according to Suryomentaram, besides thinking about the afterlife, humans also need to think about the world because he stops in the world. Finding wealth is needed as a provision (cost) to seek knowledge and fulfill basic needs of life. Science is of course used as a foundation for worship and a foundation of life, while good health will facilitate the process. All of that refers to the ultimate goal, that is to meet Allah.

Suryomentaram established six principles in meeting the needs of life, namely sakepenake, sabutuhe, saperlune, sacukupe, samesthine, and sabenere. ${ }^{60}$ He emphasized to avoid israf (excessive) behavior in fullfilling clothing, food and shelter needs.

\section{Value of Sabar in Kawruh Jiwa}

Patience is courage in facing all the tests and calamities. Patience is curbing the desire for something that is unsettling or delicacy that leaves him. ${ }^{61}$ Patience will maintain the cleanliness of the heart and ease the soul. ${ }^{62}$ Suryomentaram believes that distress is not forever, because there must be a time to change with pleasure. No one experiences pleasure for three days without difficulty, or is difficult for three days without pleasure. ${ }^{63}$ Truly happiness must come after happiness. Suryomentaram argued based on his experience seeing and reflecting on events in the community, which he exemplified in various ways such as; the desire to make his son's wedding banquet by borrowing money anywhere. If you don't get a loan, he will be ashamed and difficult because he can't entertain and invite many people. But it turned out that his shame and distress were only temporary, after he realized and passed a simple celebration, he was even grateful for failing to get a loan, because if he succeeded, he would have to think of so much debt. Patience will make someone avoid greater harm.

\footnotetext{
${ }^{58}$ Suryomentaram, Falsafah Hidup Bahagia; Jalan Menuju Aktualisasi Diri Ki Ageng Suryomentaram, compilation and translation by Grangsang Suryomentaram, (Jakarta: Panitia Kawruh Jiwa, 2010), 8.

${ }^{59}$ Suryomentaram, Buku Langgar, (n.p, 1920-1928), 19.

${ }^{60}$ Suryomentaram, Ajaran-Ajaran Ki Ageng III, 86.

${ }^{61}$ al-Qusyairi, Risalah Qusyairiyah, 258.

${ }^{62}$ Syukur, Sufi Healing, 62.

${ }^{63}$ Suryomentaram, Falsafah Hidup Bahagia, 3
} 


\section{The value of Mujahadah in Kawruh Jiwa}

Mujahadah means to be serious in curbing lust. Mujahadah is a condition that someone has noble character. ${ }^{64}$ Mujahadah is the core of Sufism. The training trains a person not to lean toward the sweetness of praise and pain from reproach. ${ }^{65}$ Kawruh Jiwo also focuses on the sincerity of supervision of desires. The term is nyawang karep, which is understanding the desires that have a sense of pleasure and a moment of difficulty. When a person has succeeded in realizing his own desires, and becomes a supervisor of his desires, then he will easily control it. ${ }^{66}$ Seriousness in researching desire (lust), will lead someone to happiness. Exercises to be free from cramps should be done consistently because manungsa without tenger can arise-sink.

\section{The value of Tawakkal in Kawruh Jiwa}

Tawakkal means surrender to qadha' and qadar from Allah. If he gets something grateful, if not he is patient and surrenders to Allah SWT. ${ }^{67}$ In another sense, it is to accept all the provisions of God, and believe that whatever God has set is the best. ${ }^{68}$ This willingness to take part in God's decree shows the level of one's closeness with Him. ${ }^{69}$

Kawruh Jiwa teaches that human taste is eternal. The sense of human who is briefly happy and briefly difficult is a nature that cannot be avoided except to receive with full courage. People who understand the law of change are happy and difficult to deal with in whatever happens in their lives. ${ }^{70}$ Sense of surrender, which is accompanied by an awareness of the existence of kesarengan gebyaring nuring Pangeran, ${ }^{71}$ will cause gandrung to the Pangeran and cause a sense of calm.

\section{Qana'ah value in Kawruh Jiwa}

Qana'ah means feeling enough with what is, and not exaggerating in trying to desire. ${ }^{72}$ Qana'ah is also the acceptance of the heart. ${ }^{73}$ Qana'ah also means leaving greedy lust and pride in property. ${ }^{74}$

\footnotetext{
${ }^{64}$ al-Ghazali, Ihya Ulumiddin, trans: Ibnu Ibrahim, (Jakarta: Republika, 2012), 205.

${ }^{65}$ al-Qusyairi, Risalah Qusyairiyah, 130.

${ }^{66}$ Suryomentaram, Falsafah Hidup Bahagia, 29.

${ }^{67}$ Harun Nasution, Filsafat dan Mistisisme dalam Islam (Jakarta: Bulan Bintang, 1995), 68.

${ }^{68}$ al-Qusyairi, Risalah Qusyairiyah, 230.

${ }^{69}$ al-Ghazali, Mukasyafatul Qulub, trans: Irwan Kurniawan (Ujungberung: Marja', 2003), 49.

${ }^{70}$ Suryoment aram, Falsafah Hidup Bahagia, 25.

${ }^{71}$ Suryoment aram, Buku Langgar, 30.

${ }^{72}$ al-Qusyairi, Risalah Qusyairiyah, 221.
} 
However, Kawruh Jiwo emphasizes life to provide what is needed only, not obeying every desire. In Kawruh terms, it is to do everything in an arbitrary way, as needed, to taste, as it should, and actually. ${ }^{75}$

\section{Value of Tawadhu (humble) in Kawruh Jiwa}

Humility is an attitude emphasized by the Sufis and is a ladder of glory. ${ }^{76}$ Tawadhu means to be low in front of others and to be gentle towards them. Tawadhu' also means not seeing that he has a position and does not view other people as bad. ${ }^{77}$

Kawruh Jiwa teaches about the same feeling, which is the feeling that all humans share, that it is difficult and happy to take turns, so it is inappropriate for someone to be arrogant and envious. People who understand the same sense, will understand that in this life, there is no point in overcoming each other and competing with others, because in the end it is difficult and happy to be something that comes in turn for everyone. One must exceed and be exceeded, there will never be more than everyone on earth. People who understand it can certainly act laughing and reach peace of mind. ${ }^{78}$

\section{Is ar value (prioritizing others) in Kawruh Jiwa}

Iśar in Sufism occupies a high value. Is்ar means giving priority to others, more than oneself. ${ }^{79}$ Kawruh Jiwa teaches about the fourth measure, which is human taste. The motto is, "Whoever is looking for good without the neighbor, making a rope to trap his own neck." In Kawruh Jiwa, the feeling of goodness is only achieved by making other people feel good. ${ }^{80}$

Kawruh Jiwa discusses how we behave and respond to relationships with others. By observing how we respond to the attitudes of others, how we react, it will appear whether we are still dominated by superiority and fear, whether in responding to other people's attitudes, we are still shackled by superiority and fear, whether in responding to others, we want to always excel, and fear if others outperform us.

\section{Value of Fear (Khauf) in Kawruh Jiwa}

\footnotetext{
${ }^{73}$ Syukur, Sufi Healing, 62

${ }^{74}$ Sayyid Bakri al-Makki, Merambah Jalan Sufi, trans: A. Wahid, (Bandung: Sinar Baru Algensindo, 2004), 28

${ }^{75}$ Suryomentaram, Falsafah Hidup Bahagia,18.

${ }^{76}$ al-Sulami, Muqaddimah Tasawuf, trans: Faisal Saleh, (Jakarta: Erlangga, 2007), 139.

${ }^{77}$ al-Qusyairi, Risalah Qusyairiyah, 202.

${ }^{78}$ Suryomentaram, Falsafah Hidup Bahagia, 17-18.

${ }^{79}$ Amin Syukur, Menggugat Tasawuf: Sufisme dan Tanggungjawab Sosial Abad 21 (Yogyakarta: Pustaka Pelajar, 1999), 90.

${ }^{80}$ Suryomentaram, Falsafah Hidup Bahagia, 47-48.
} 
Fear in Kawruh Jiwo starts from fear of intimidation, fear of death, fear of a fut ure that has not yet been seen. Fear of someone who is competing, or more of him in any case, whether in worldliness (semat, drajat, kramat) and in matters of religion and wisdom. This fear is what drives people to make every effort so they can always exceed others. This is a fear that is actually unnatural.

To achieve human without atribute status, it takes effort as much as possible to be sustainable, but the purpose of doing business is not to gain excellence before humans, because it is contrary to the feeling that results from understanding and selfappreciation. People who know themselves, then they will not trouble themselves in order to exceed other people in any case. He will achieve the tranquility of the soul by making other people feel. If so, then he is free from fear of being surpassed, afraid of his honor and sacredness.

Kawruh Jiwa discusses how we behave and respond in association with others. By observing how we respond to the attitudes of others, how we react, it will appear whether we are still dominated by superiority and fear, whether in responding to other people's attitudes, we are still shackled by superiority and fear, whether we are responding other people, we want to always excel, and fear if others outperform us.

The second fear is fear of death. Courage to die inspired Suryomentaram to find the war talisman during the war of independence, which was to die in the framework of jihad to defend the country.

\section{Value of Hope (Raja') in Kawruh Jiwa}

In addition to developing ways to process fear to be positive, Kawruh Jiwa counterbalances it with hope, a sense of future-oriented, hoping for goodness, creating optimism and confidence in facing life. After humans felt helpless and resigned, then the will emerged to support this sense of helplessness to become optimistic surrender, not surrender. This life is a vehicle with many problems, but there are no problems that cannot be resolved. In chaotic souls, the main capital to solve problems is to think and feel.

\section{Yaqin Value in Kawruh Jiwa}

As-Sarraj, ${ }^{81}$ divides the level of yaqin into three conditions; first is the beginner class (students and lay people), which is to believe what is in God's hands and pessimistic about what is in the hands of humans. Continued with the opinion of Imam al-Junaid, that true belief is the loss of doubt. Second, the middle class, true belief is the continuity of various obstacles throughout time, true belief is musyahadah. Third, the

${ }^{81} \mathrm{Abu}$ Nashr as-Sarraj, al-Luma', 146-147. 
Sufi elite group, true belief is breaking all the causes that hinder a person from Allah, from the sky to the earth, so that there is only Allah.

However, the soul always tries to break the human ego from the hope of beings. Do good because you want to get rewarded, praise for wanting to be praised, worshiped and obedient to someone who is richer and more powerful, depending on humans to forget their own humanity. In worshiping God, Suryomentaram sets the standard for worshiping the right and the wrong. The true worship must be based on bad luck, in this context bad luck means feeling small and helpless, so he realizes with his clarity of mind that something is able to make the sun rise and sink and move the wind. He is the Almighty. The belief that a person has must be based on understanding, not just be confident in speech without being able to understand and absorb in his heart. If belief is embedded, then one's behavior becomes happy and kejawahan kawruh (the rain of knowledge).

\section{The Value of Ridha in Kawruh Jiwa}

Suryomentaram interpreted it as feeling inclined or happy. Nice to whatever Allah has outlined, both what happens to the universe and what happens in his mind. All by the will of Allah. People who have surrendered, sincere, sure, then he is willing to all that God wants. Willing to show a calm, accepting, positive inner attitude, but knowing that everything is real, true and peaceful.

\section{G. Conclusion}

Sufistic values contained in the Kawruh Jiwo of Suryomentaram include the value of taubat, zuhud, sabar, mujahadah, tawakkal, qana'ah, tawadhu, itsar, raja', khauf, yaqin, and ridha. To achieve these values, the concept of liberation from selfishness and lust is pursued through a process of self-awareness, taking distance with yourself, being a selfsupervisor, and doing a kandha-takon (question and answer) with yourself. This process will lead someone to take the right decisions and actions, namely noble behavior or morals. Understanding, living and practicing the same feeling, will form a sense of empathy, be kind in thought, and be free from feelings of pride. Loving (raos asih) to yourself and others simultaneously, creating a hablumminannas character that can lead someone to hablumminallah. All of this shows that Kawruh Jiwa of Suryomentaram is in line with Sufism, in order to form noble values. Kawruh Jiwa is a teaching that is full of sufistic values, enriches those values, and makes them easy to apply in everyday life.

\section{Bibliography}

Bakhtiar, Laleh. Mengenal Ajaran Kaum Sufi, Translated by Purwanto. Ujungberung: Marja, 2008.

Bertens, K. Etika. Jakarta: Gramedia, 1993. 
Boneff, Marcell, "Ki Ageng Suryomentaram, Pangeran dan Filsuf dari Jawa" (18921962), dalam Afthonul Afif, Matahari dari Mataram, Menyelami Spiritalitas Jawa Rasional Ki Ageng Suryomentaram. Depok: Penerbit Kepik, 2012.

Frager, Robert. Psikologi Sufi. Translated by Hasmiyah Rauf. Jakarta: Zaman, 2014.

al-Ghazali. Ihya Ulumuddin. Translated by Ibnu Ibrahim. Jakarta: Republika, 2012.

al-Ghazali. Mukasyafatul Qulub. Translated by Irwan Kurniawan. Ujungberung: Marja', 2003.

al-Hujwiri. Kasyful Mahjub. Translated by Suwardjo Muthary. Bandung: Mizan, 1997.

Khalim, Samidi. Islam dan Spiritualitas Jawa. Semarang: RaSAIL Media, 2008.

Mantyasih, Ki Ageng. Kawruh Begja Sawetah; Jabaran Ilmu Keberuntungan Ki Ageng Suryomentaram. Semarang: Dahara Prize, 2013.

al-Makki, Sayyid Bakri. Merambah Jalan Sufi. Translated by A. Wahid. Bandung: Sinar Baru Algensindo, 2004.

Miswar, "Maqamat: Tahapan yang Harus Ditempuh dalam Proses Bertasawuf", Jurnal IANSIRUPA, Vol. 1, No. 2, 2017.

Nasution, Harun. Falsafat dan Mistisisme dalam Islam. Jakarta: Bulan Bintang, 1995.

al-Qusyairi. Risalah Qusyairiyah. Translated by Umar Faruq. Jakarta: Pustaka Amani, 2013.

Rakhman, Muhammad Zainur. Mantyasih; Kitab Keabadian Cinta. Yogyakarta: Garudhawaca, 2016.

Rusdy, Sri Teddy. Epistemologi Ki Ageng Suryomentaram Tandhesan Kawruh Bab Kawruh. Jakarta: Yayasan Kertagama, 2014.

as-Sarraj, Abu Nashr. al-Luma': Rujukan Lengkap Ilmu Tasawuf. Translated by Wasmukan. Surabaya: Risalah Gusti, 2014.

Simuh. Sufisme Jawa. Yogyakarta: Narasi, 2016.

Solihin, M. Melacak Pemikiran Tasawuf di Nusantara. Jakarta: Raja Grafindo Persada, 2005.

Sugiarto, Ryan. Psikologi Raos Saintifikasi Kawruh Jiwa Ki Ageng Suryomentaram. Yogyakarta: Pustaka Ifada, 2015.

as-Sulami. Muqaddimah Tasawuf. Translated by Faisal Saleh. Jakarta: Erlangga, 2007.

Suryomentaram, Buku Langgar, manuscripts circulating in Paguyuban Pelajar Kawruh Jiwa.

Suryomentaram. Ajaran-ajaran Ki Ageng Suryomentaram Jilid I. Jakarta: Inti Idayu Press, 1985. 
Suryomentaram. Ajaran-Ajaran Ki Ageng Suryomentaram Jilid II. Jakarta: Inti Idayu Press, 1986.

Suryomentaram. Ajaran-ajaran Ki Ageng Suryomentaram Jilid III. Jakarta: Inti Idayu Press, 1986.

Suryomentaram. Falsafah Hidup Bahagia; Jalan Menuju Aktualisasi Diri Ki Ageng Suryomentaram. Collected and translated by Grangsang Suryomentaram. Jakarta: Panitia Kawruh Jiwa, 2010.

Suseno, Franz Magniz. Etika Jawa. Jakarta: Gramedia, 2003.

Syukur, Amin. Sufi Healing. Jakarta: Erlangga, 2012.

Syukur, Amin. Zuhud di Abad Modern. Yogyakarta: Pustaka Pelajar, 1997.

Syukur, Amin. Menggugat Tasawuf: Sufisme dan Tanggungjawab Sosial Abad 21. Yogyakarta: Pustaka Pelajar, 1999.

Wahyudi, Agus. Rahasia Kesempurnaan Makrifat Para Wali Jawa. Yogyakarta: Lingkaran, 2003.

Walters, Donald. Crises in Modern Thought. Translated by Widhi Nugraha. Jakarta: Gramedia, 2003.

Wilcox, Lynn. Ilmu Jiwa Berjumpa Tasawuf. Translated by Harimurti. Jakarta: Serambi, 2003. 
